\title{
Abdominal cocoon syndrome as a rare cause of mechanical bowel obstruction: report of two cases
}

\author{
Bağırsak tıkanıklığının nadir bir sebebi olan abdominal koza sendromu: \\ İki olgu sunumu
}

\author{
Levent YENİAY, Can Avni KARACA, Cemil ÇALIŞKAN, \\ Özgür FIRAT, Sinan Muhtar ERSİN, Erhan AKGÜN
}

\begin{abstract}
An abdominal cocoon is an extremely rare condition, and has been reported mainly in young adolescent women as a cause of small bowel obstruction. In these patients, the small bowel is encased in a fibrous sac called an abdominal cocoon. We hereby present two cases who were diagnosed only by laparotomy and their correlation with the literature. They both received early intervention, thus preventing the need for bowel resection. The pathology of both membranes showed inflammation.
\end{abstract}

Key Words: Abdominal cocoon; peritoneal encapsulation.
Abdominal koza literatürde genelde genç adölesan kadınlarda ince bağırsak tıkanıklığının bir nedeni olarak bildirilen nadir bir durumdur. Bu hastalarda ince bağırsak "abdominal koza" olarak adlandırılan fibröz bir kese içine sarılmıştır. Biz burada tanısı ancak laparotomi ile konulabilen iki olguyu literatürdeki bilgilerle birlikte sunuyoruz. Her iki olguya da erken dönemde müdahale edilerek bağırsak rezeksiyonundan kaçınılmıştır. Her iki olguda da membranın patolojik incelemesi enflamatuvar bir sürece işaret etmiştir.

Anahtar Sözcükler: Abdominal koza; periton kapsülleme.
Abdominal cocoon syndrome describes the condition of partial or total encapsulation of abdominal viscera within a dense fibrous membrane, and was first described by Foo et al. ${ }^{[1]}$ in 1978 . The majority of the cases are reported from tropical and subtropical climate belts of the world. To our best knowledge, the only case reported from a non-tropical zone is from England, in which the case was born in Pakistan. ${ }^{[2]}$

Several theories have been suggested regarding the etiology of the disease, but the majority of the cases are of unknown etiology. ${ }^{[3]}$

Herein, we present two cases of idiopathic abdominal cocoon syndrome who were treated successfully in our surgery department, together with a brief review of the literature.

\section{CASE REPORTS}

Case 1- A 26-year-old female patient was admitted to the emergency department with the complaints of colic abdominal pain and vomiting persisting for two days. There were similar episodes with spontaneous symptomatic relief in the detailed history of the patient. Anamnesis revealed no history of chronic illness, chronic medication or previous operation.

In the physical examination, there were signs of peritoneal irritation especially in the lower quadrants of the abdomen with rebound tenderness. No distention was observed and the bowel sounds were attenuated. Air fluid levels were seen in plain abdominal $\mathrm{X}$-rays, and a computerized tomography revealed distended small bowels to the level of the terminal ileum. 

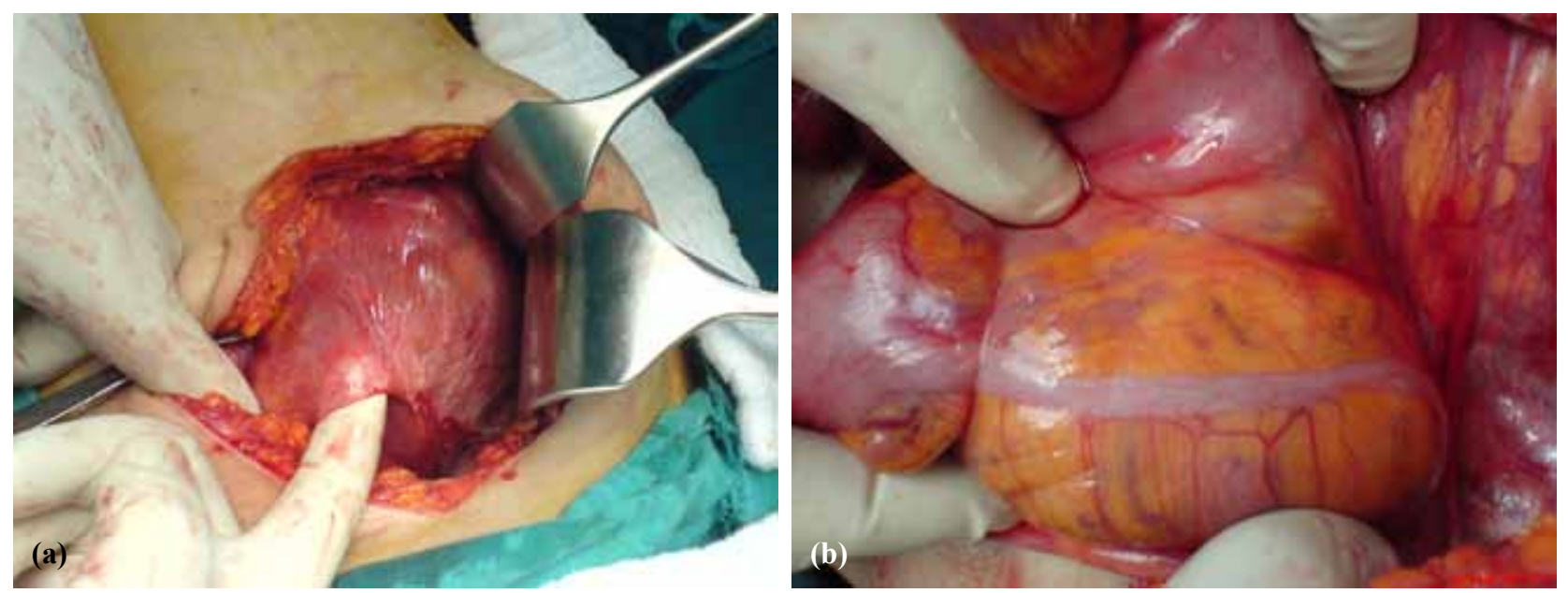

Fig. 1. Case 1. (a) Bowels and the abdominal viscera were found to be under a thick and dense membrane. (b) The appendix was firmly adhered to the cecal wall.

(Color figure can be viewed in the online issue, which is available at www.tjtes.org)

Blood chemistry, total blood count and urine analysis showed no abnormality except a slight elevation of Creactive protein.

The patient was then explored based on the diagnosis of acute abdomen. In the operational observation, bowels and the abdominal viscera were found to be under a thick and dense membrane, and the obstruction site causing the symptoms was a short small bowel segment adjacent to the ileocecal valve (Fig. 1a). The appendix was firmly adhered to the cecal wall (Fig. 1b). There was no major omentum present.

The patient underwent simply bridectomy; no resection was performed. After the incision of the membrane, the bowels were freed, leaving no narrowed segment. The postoperative course was uncomplicated. The patient was allowed to feed via oral route by the 3rd postoperative day, and stool discharge occurred on the 4 th postoperative day.
The diagnosis was made perioperatively, and the patient was further questioned regarding secondary causes of abdominal cocoon syndrome. There was no positive history of these causes, which are reviewed in the Discussion section.

The patient was discharged on the 6 th postoperative day.

The histopathologic analysis of the specimen was reported as fibrosis, inflammation and fibrin exudation.

The patient is doing well on follow-up, with no symptoms of bowel obstruction.

Case 2- A 71-year-old male patient was admitted to the emergency department with the complaint of profuse vomiting after meals and absence of gas discharge for nearly two days. He described three similar episodes with spontaneous symptomatic relief within three months. He had no chronic disease.
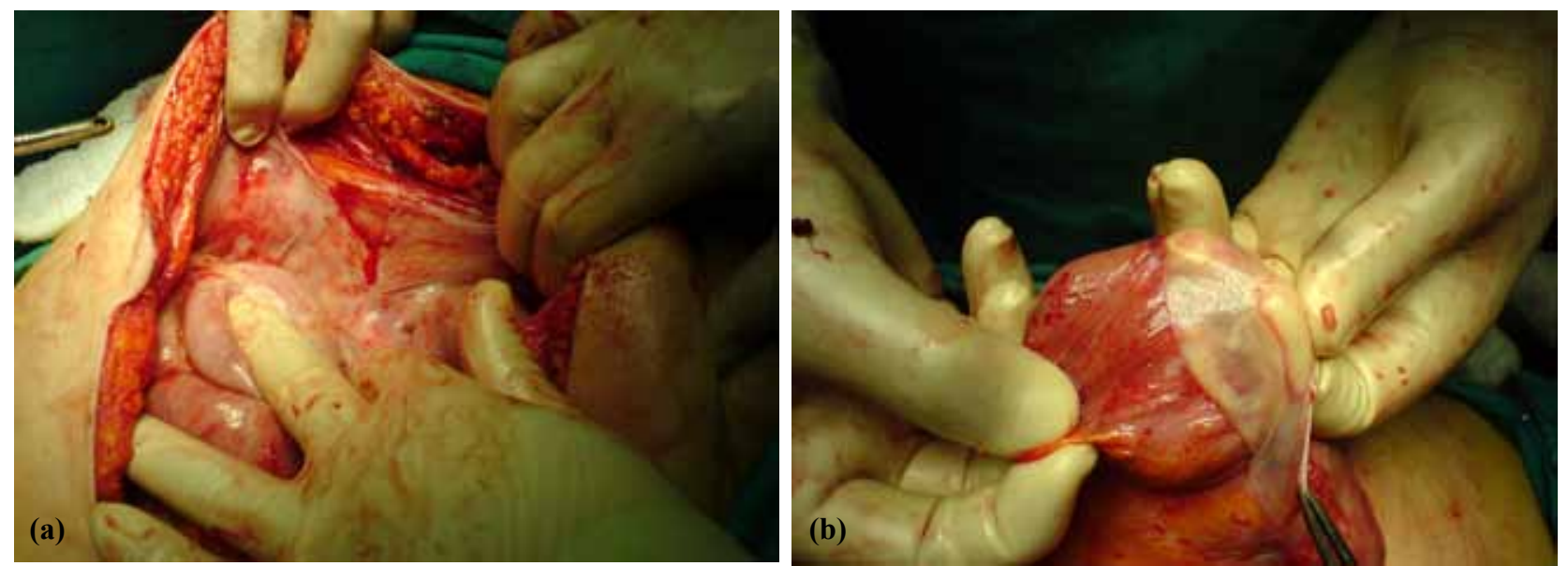

Fig. 2. Case 2. A cardinal symptom of mechanical bowel obstruction.

(Color figure can be viewed in the online issue, which is available at www.tjtes.org) 
Palpation of the upper quadrants of the abdomen was painful with rebound tenderness. There was a soft palpable mass located in the left quadrants of the abdomen. No distention was observed, and the bowel sounds were not altered. Plain X-rays of the abdomen showed no significant pathologic sign. Abdominal computerized tomography revealed distention of stomach, duodenum and a short segment of the proximal jejunum with a small amount of fluid collection around the stomach. The tomography reported a clustering of bowels to the left quadrants of the abdomen. The blood chemistry and total blood count showed no abnormality.

The patient underwent an emergency laparotomy with a diagnosis of acute abdomen. During the operational evaluation, the bowels were found to be encapsulated in a thick membrane causing obstruction, but preventing the distention, which is a cardinal symptom of mechanical bowel obstruction (Fig. 2a, b). As observed in the first case, the major omentum was missing.

The patient underwent simple bridectomy, and the adhesions were freed by careful dissections in order to prevent iatrogenic bowel injuries, which are frequently reported in the literature in similar cases. The postoperative course was uneventful. Enteral feeding started on the 2nd postoperative day, and stool discharge occurred on the 6th postoperative day.

As in the first case, the diagnosis was done perioperatively. Since there was no positive history of secondary causes, the case was admitted as primary abdominal cocoon syndrome. The patient was discharged on the 8th postoperative day.

The histopathologic analysis of the specimen revealed fibrosis and granulomatous inflammation.

Follow-up of the patient was unproblematic, with no symptoms of bowel obstruction.

\section{DISCUSSION}

An abdominal cocoon was first described and named by Foo et al. ${ }^{[1]}$ in 1978. An abdominal cocoon is a form of intestinal encapsulation, which is mostly observed in young girls living in tropical and subtropical regions. ${ }^{[1,4,5]}$ In contrast to peritoneal encapsulation, the encasing membrane is an opaque fibrous structure, which is not covered by a mesothelium. In the vast majority of the cases, the histological evaluation of the membrane shows inflammation.

The pathogenesis of abdominal cocoon syndrome remains unknown; however, the etiopathogenesis correlates to congenital dysplasia, chronic asymptomatic peritonitis, some medicines (e.g., practolol), continuous ambulatory peritoneal dialysis, and district and sexuality factors. ${ }^{[6,7]}$ None of these secondary pathogenetic factors was encountered in our cases. The absence of the major omentum in both of our cases may suggest the association of some unknown genetic factors that play a role in the pathogenesis of idiopathic disease. ${ }^{[8]}$

The clinical presentation of the abdominal cocoon syndrome mostly occurs as acute abdomen, which, in most cases, requires surgical intervention. Preoperative diagnosis of the syndrome is usually difficult. There are four main clinical features suggested in the literature by Yip and Lee ${ }^{[9]}$ for preoperative diagnosis. These are:

A relatively young female patient without an obvious cause of bowel obstruction.

Past history of similar episodes with symptomatic relief.

Presentation with symptoms suggestive of bowel obstruction but absence of cardinal symptoms such as distention.

\section{Presence of soft non-tender abdominal mass.}

Our first case fits most of the features above except for the presence of a palpable mass. The latter also fits these features except for the patient being an elderly male patient. All these clinical features allowed us to suspect the diagnosis of abdominal cocoon syndrome. This led us to decide laparotomy earlier, thus preventing strangulation and resection of the bowel.

However, the definitive diagnosis is achieved under laparotomy. In the literature, typically, the appearance of the abdomen is described as the bowels being in a coil-like pattern with a dense thick membrane covering the small bowels totally or partially. ${ }^{[10]}$ In some distinct cases, this membrane can cover the large intestine and even solid organs. In both of our cases, the membrane fully covered both the small and large intestine, but left the solid viscera uncovered. ${ }^{[10]}$

The treatment of choice for abdominal cocoon syndrome is lysis of adhesions or total removal of the membrane.

In summary, abdominal cocoon syndrome is rare and difficult to diagnose. A better awareness of the entity, plus a combination of clinical examination and radiologic studies, may facilitate the preoperative diagnosis. Suitable and early surgery and appropriate perioperative treatment can improve patient prognosis in this rare condition.

\section{REFERENCES}

1. Foo KT, Ng KC, Rauff A, Foong WC, Sinniah R. Unusual small intestinal obstruction in adolescent girls: the abdominal cocoon. Br J Surg 1978;65:427-30.

2. Macklin J, Hall C, Feldman MA. Unusual cause of small 
bowel obstruction in adolescent girls: the abdominal cocoon. J R Coll Surg Edinb 1991;36:50-2.

3. Kumar M, Deb M, Parshad R. Abdominal cocoon: report of a case. Surg Today 2000;30:950-3.

4. Bhatnagar A, Pathania OP, Malik V, Chowdhry A. Abdominal cocoon causing small bowel obstruction. Indian J Gastroenterol 1987;6:55-6.

5. Ahmed MN, Kaur S, Zargar HU. Abdominal cocoon: an unusual intestinal obstruction (a case report). J Postgrad Med 1984;30:62-3.

6. Afthentopoulos IE, Passadakis P, Oreopoulos DG, Bargman J. Sclerosing peritonitis in continuous ambulatory peritoneal dialysis patients: one center's experience and review of the literature. Adv Ren Replace Ther 1998;5:157-67.

7. Mann RD. An instructive example of a long-latency adverse drug reaction--sclerosing peritonitis due to practolol. Pharmacoepidemiol Drug Saf 2007;16:1211-6.

8. Wei B, Wei HB, Guo WP, Zheng ZH, Huang Y, Hu BG, et al. Diagnosis and treatment of abdominal cocoon: a report of 24 cases. Am J Surg 2009;198:348-53.

9. Yip FW, Lee SH. The abdominal cocoon. Aust N Z J Surg 1992;62:638-42.

10. Sieck JO, Cowgill R, Larkworthy W. Peritoneal encapsulation and abdominal cocoon. Case reports and a review of the literature. Gastroenterology 1983;84:1597-1601. 